Article

\title{
Durability of Alternative Metal Oxide Supports for Application at a Proton-Exchange Membrane Fuel Cell Cathode-Comparison of Antimony- and Niobium-Doped Tin Oxide
}

\author{
Laetitia Dubau ${ }^{1, *}$, Frédéric Maillard ${ }^{1}\left(\mathbb{D}\right.$, Marian Chatenet ${ }^{1, *} \mathbb{C}$, Sara Cavaliere ${ }^{2,3} \mathbb{C}^{\circ}$, \\ Ignacio Jiménez-Morales ${ }^{2}$, Annette Mosdale ${ }^{4}$ and Renaut Mosdale ${ }^{4}$ \\ 1 University Grenoble Alpes, University Savoie Mont Blanc, CNRS, Grenoble INP, LEPMI, \\ 38000 Grenoble, France; frederic.maillard@lepmi.grenoble-inp.fr \\ 2 Institut Charles Gerhardt Montpellier, UMR 5253, CNRS, Université Montpellier, ENSCM, \\ Place Eugène Bataillon, 34095 Montpellier CEDEX 5, France; sara.cavaliere@umontpellier.fr (S.C.); \\ ignacio.jimenez-morales@univ-montp2.fr (I.J.-M.) \\ 3 Institut Universitaire de France (IUF), 75231 Paris CEDEX 05, France \\ 4 Paxitech, 38130 Echirolles, France; a.mosdale@orange.fr (A.M.); renaut.mosdale@paxitech.com (R.M.) \\ * Correspondence: laetitia.dubau@lepmi.grenoble-inp.fr (L.D.); marian.chatenet@grenoble-inp.fr (M.C.); \\ Tel.: +33-476-82-65-92 (L.D.); +33-476-82-65-88 (M.C.)
}

Received: 6 December 2019; Accepted: 10 January 2020; Published: 14 January 2020

\begin{abstract}
In this study, the resistance to corrosion of niobium-doped tin dioxide ( $\mathrm{Nb}$-doped $\left.\mathrm{SnO}_{2}, \mathrm{NTO}\right)$ and antimony-doped tin oxide (Sb-doped $\mathrm{SnO}_{2}, \mathrm{ATO}$ ) supports has been probed for proton-exchange membrane fuel cell (PEMFC) application. To achieve this goal, ATO or NTO supports with loose-tube (fiber-in-tube) morphology were synthesized using electrospinning and decorated with platinum $\mathrm{Pt}$ ) nanoparticles. These cathode catalysts were submitted to two different electrochemical tests, an accelerated stress test following the EU Harmonised Test Protocols for PEMFC in a single cell configuration and an $850 \mathrm{~h}$ test in real air-breathing PEMFC systems. In both cases, the dissolution of the doping element was measured either by inductively coupled plasma mass spectrometry (ICP-MS) performed on the exhaust water or by energy dispersive X-ray spectrometry (X-EDS) analysis on ultramicrotomed membrane electrode assembly (MEA), and correlated to the performance losses upon ageing. It appears that the NTO-based support leads to lower performances than the ATO-based one, mainly owing to the low electronic conductivity of NTO. However, in the case of ATO, dissolution of the $\mathrm{Sb}$ doping element is non-negligible and represents a major issue from a stability point-of-view.
\end{abstract}

Keywords: proton-exchange membrane fuel cell; durability; degradation mechanism; metal oxide support; antimony-doped tin oxide; niobium-doped tin oxide; loose tube

\section{Introduction}

Because it is easily stored and transported, dihydrogen $\left(\mathrm{H}_{2}\right)$ is an excellent energy carrier with an energy density of $33 \mathrm{kWh} \mathrm{kg}^{-1}$, which is 3-fold and 2.5-fold those of diesel and methane, respectively. Used in a fuel cell, $\mathrm{H}_{2}$ produces electrical energy and releases only water. However, in proton-exchange membrane fuel cells (PEMFCs), the ideal fuel cell technology for transportation applications, the high electrochemical potential, presence of water and oxygen, acidic $\mathrm{pH}$, and production of free radicals during cathodic reaction favor the degradation of carbon-supported $\mathrm{Pt}$ or $\mathrm{Pt}$ alloy nanoparticles (NPs). Studies in real-life PEMFC operating conditions [1] or in conditions simulating PEMFC cathode operation [2,3] have shown that (i) platinum (Pt) and Pt alloy NPs are corroded via direct 
electrochemical oxidation ( $\mathrm{Pt} \rightarrow \mathrm{Pt}^{2+}+2 \mathrm{e}^{-}$) or via a coupled electrochemical-chemical dissolution $\left(\mathrm{Pt}+\mathrm{H}_{2} \mathrm{O} \rightarrow \mathrm{PtO}+2 \mathrm{H}^{+}+2 \mathrm{e}^{-}\right.$followed by $\left.\mathrm{PtO}+2 \mathrm{H}^{+} \rightarrow \mathrm{Pt}^{2+}+\mathrm{H}_{2} \mathrm{O}\right)$. Moreover, due to variation of the electrochemical potential between idling and load conditions, dissolution of $\mathrm{Pt}$ may occur continuously [4-7]. Dissolution of Pt preferentially leads to an increase in the size of the NPs via the so-called "3D Ostwald ripening", where the dissolved $\mathrm{Pt}^{\mathrm{Z}+}$ species redeposit onto the largest NPs or into the ionomer and proton-exchange membrane (PEM) [1]. In the latter case, the Pt NPs are not only electrochemically inactive but boost the degradation of the PEM $[1,8]$. High surface area carbons used as supports are also prone to corrosion in PEMFC cathode operating conditions, and the extent of degradation essentially depends on the PEMFC operating temperature [9-17], relative humidity $[3,10,18,19]$, current density/potential [17,20], and duration of operation [20-23]. In stationary operation, there is formation of oxygen-containing carbon surface groups, such as alcohols, quinones, or carboxylic acids [24]. These groups have antagonistic influences: on the positive side, they share electron density with the Pt NPs via their oxygen atoms [25-31] and thus facilitate their resistance to sintering $[14,32,33]$; on the negative side, the presence of Pt NPs speeds up the carbon oxidation reaction (COR) kinetics by assisting the complete oxidation of these carbon surface groups into $\mathrm{CO}_{2}[24,34,35]$. Specifically, water dissociation at the Pt NPs at $c a .0 .6 \mathrm{~V}$ vs. the reversible hydrogen electrode (RHE) accelerates electrooxidation of the oxygen-containing carbon surface groups [9,10,19,24,32,34]. In addition, during periods where the cathode undergoes reducing conditions (e.g., upon $\mathrm{H}_{2}$ crossover from anode to cathode at stops [16]), the carbon support may depassivate, which facilitates the migration, agglomeration and, ultimately, coalescence of the Pt NPs [33]. However, the worst scenario occurs during startup/shutdown (SU/SD) of the PEMFC or in fuel starvation conditions, during which the potential of the cathode reaches as high as $1.6 \mathrm{~V}$ vs. RHE $[13,36,37]$. These conditions facilitate the collapse of the porous structure of the electrode and the detachment of the Pt-based NPs from the support, and the remaining carbon domains become less electron-conducting due to transformation of graphitic carbon domains ( $\mathrm{sp}^{2}$ hybridization) into amorphous carbon $\left(\mathrm{sp}^{3}\right.$ hybridization).

Different materials strategies have been introduced to prevent the adverse effects of COR in operating PEMFC cathodes. A carbon-based strategy consists of using more graphitic supports, such as carbon nanotubes (single-wall or multi-wall) or thermally annealed carbon-based supports, but it will only delay and not solve the COR issue. Another strategy consists of using transition metal-based supports, and Sasaki et al. [38] have shown that six metal oxides $\left(\mathrm{MO}_{\mathbf{x}}\right)$ can be viable alternatives to carbon blacks at a PEMFC cathode: $\mathrm{MoO}_{3}, \mathrm{Nb}_{2} \mathrm{O}_{5}, \mathrm{TiO}_{2}, \mathrm{SnO}_{2}, \mathrm{Ta}_{2} \mathrm{O}_{5}$, and $\mathrm{WO}_{3}$. Nevertheless, $\mathrm{MO}_{\mathrm{x}}$ can be considered as insulators when their band gap exceeds $1 \mathrm{eV}$, and $\mathrm{MoO}_{3}, \mathrm{Nb}_{2} \mathrm{O}_{5}, \mathrm{TiO}_{2}$, $\mathrm{SnO}_{2}, \mathrm{Ta}_{2} \mathrm{O}_{5}$, and $\mathrm{WO}_{3}$ feature 3.2-3.4-3.2-3.2-3.5-4.3 and $2.7 \mathrm{eV}$ band gap, respectively. This leads to electrical conductivity values comprised between $10^{-11} \mathrm{~S} \mathrm{~cm}^{-1}$ and $10^{-7}-10^{-6} \mathrm{~S} \mathrm{~cm}^{-1}$ for $\mathrm{SnO}_{2}, \mathrm{Ta}_{2} \mathrm{O}_{5}$, and $\mathrm{Nb}_{2} \mathrm{O}_{5}[39,40]$ : thus, doping becomes a prerequisite for forming a degenerate semi-conductor (i.e., featuring a number of mobile charge carriers in the range $\sim 10^{19} \mathrm{~cm}^{-3}$ ) and enables sufficient electronic conductivity for practical use of these materials in PEMFC cathodes. For doping to be efficient, the heteroatom must feature a higher number of valence electrons than the atom to which it is substituted. In addition, the introduced heteroatom must have an ionic radius close to the $\mathrm{M}$ atoms in the $\mathrm{MO}_{\mathrm{x}}$. Based on these requirements, $\mathrm{Nb}, \mathrm{Ta}$, and $\mathrm{Sb}$ appear to be appropriate substitutes for $\mathrm{Ti}$ or $\mathrm{Sn}$ atoms in the respective $\mathrm{MO}_{\mathrm{x}}$ [41]. The efficiency of doping may also be checked experimentally, e.g., the specific surface area of $\mathrm{Pt}$ NPs deposited onto $\mathrm{MO}_{\mathrm{x}}$ increases from $15-20 \mathrm{~m}^{2} \mathrm{~g}^{-1}$ on undoped tin oxide $\left(\mathrm{SnO}_{2}\right)$ support [42-45] to $20-80 \mathrm{~m}^{2} \mathrm{~g}^{-1}$ upon doping [46-60]. The electrocatalytic activity towards the oxygen reduction reaction is also influenced by the electronic conductivity of the $\mathrm{MO}_{\mathrm{x}}$ support: Takasaki et al. [42] observed a $60 \%$ increase in mass activity toward the oxygen reduction reaction (ORR) between a $\mathrm{Pt} / \mathrm{SnO}_{2}$ and $\mathrm{Pt} / \mathrm{Sn}_{0.95} \mathrm{Sb}_{0.05} \mathrm{O}_{2}$ catalyst. Nevertheless, the lack of resistance to corrosion of the doped $\mathrm{MO}_{\mathrm{x}}$ casts doubts on their long-term viability. For $\mathrm{SnO}_{2}$, one of the most promising $\mathrm{MO}_{\mathrm{x}}$ for application in a PEMFC cathode, Kakinuma et al. [61] reported no leaching of the doping element ( $\mathrm{Nb}$ or $\mathrm{Sb}$ ) from $\mathrm{Pt} / \mathrm{Sn}_{0.96} \mathrm{Nb}_{0.04} \mathrm{O}_{2-\delta}$ and $\mathrm{Pt} / \mathrm{Sn}_{0.96} \mathrm{Sb}_{0.04} \mathrm{O}_{2-\delta}$ catalysts after a 3-week exposure in $\mathrm{H}_{2} \mathrm{SO}_{4}$ at $\mathrm{T}=80^{\circ} \mathrm{C}$ under reducing $\left(\mathrm{H}_{2}\right.$ bubbling) or oxidizing (air bubbling) conditions. 
However, $\mathrm{Sn}^{2+}$ species were detected for the two doped $\mathrm{MO}_{\mathrm{x}}$. Similar results were reported by Senoo et al. [52] for Ta- or $\mathrm{Nb}$-doped $\mathrm{SnO}_{2-\delta}$. Using $\mathrm{Sn}_{0.95} \mathrm{Sb}_{0.05} \mathrm{O}_{2}$ support calcined at $550{ }^{\circ} \mathrm{C}$ for $2 \mathrm{~h}$ or $10 \mathrm{~h}$, Fabbri et al. [51] reported that the antimony (Sb) distribution influences the long-term resistance of antimony-doped tin oxide ( $\mathrm{Sb}$-doped $\mathrm{SnO}_{2}$, ATO); after 1000 cycles between $0.05<E$ $<1.6 \mathrm{~V}$ vs. RHE, the $2 \mathrm{~h}$-calcined support had a homogeneous composition identical to its initial state, while the $10 \mathrm{~h}$-calcined support had lost nearly $100 \% \mathrm{Sb}$. Using inductively coupled plasma mass spectrometry (ICP-MS), Cognard et al. [56,57] confirmed that $\mathrm{Sb}$ and $\mathrm{Sn}$ atoms both dissolve from the ATO support, adsorb onto Pt, and therefore poison the Pt catalytic sites, with the process being accelerated during excursions to low electrode potential, e.g., during kinetic measurements and electrochemical characterizations [57]. Using ex situ and in situ electrochemical characterization coupled with probe spectroscopic techniques, Jiménez-Morales et al. [59] evidenced that Sb leaching from ATO fiber-in-tubes was the origin of the instability of this material at potentials $E<0.5 \mathrm{~V}$ vs. RHE and $E>2.0 \mathrm{~V}$ vs. RHE. The loss of the doping agent compromises the support electrical conductivity and deactivates the catalyst active sites, leading to performance decrease. This short literature review shows that $\mathrm{MO}_{\mathrm{x}}$ supports hold promise, but also that more work is required to probe their interest (or not) for usage as Pt NPs support in PEMFC cathodes.

In this study, we probe the resistance to corrosion of niobium-doped tin dioxide $\left(\mathrm{Nb}\right.$-doped $\mathrm{SnO}_{2}$, NTO) and ATO supports in air-breathing PEMFC systems. Toward this goal, we synthesized ATO or NTO supports with loose-tube (fiber-in-tube) morphology using electrospinning, decorated them with Pt NPs, and operated them following two different tests (an accelerated stress test based on the "EU Harmonised Test Protocols for PEMFC MEA Testing in Single Cell Configuration for Automotive Applications", and a long-term test in planar fuel cell configuration).

\section{Materials and Methods}

\subsection{Synthesis of Pt/ATO and Pt/NTO}

$\mathrm{SnO}_{2}$ materials doped with $\mathrm{Sb}$ or $\mathrm{Nb}$ were prepared by electrospinning followed by thermal treatment according to a previously published procedure [53,62]. Briefly, a solution containing the inorganic precursors and carrier polymer was prepared $0.10 \mathrm{~g}$ of $\mathrm{SbCl}_{3}(99 \%$, Sigma-Aldrich, St. Louis, MO, USA) or $0.06 \mathrm{~g}$ of $\mathrm{NbCl}_{5}$ ( $98 \%$ min., Merck, Darmstadt, Germany), $0.78 \mathrm{~g}$ of $\mathrm{SnCl}_{2}\left(98 \%\right.$, Sigma-Aldrich), and $0.80 \mathrm{~g}$ of polyvinylpyrrolidone (average $\mathrm{M}_{\mathrm{W}} \sim 1,300,000$, Aldrich) in a mixture of $3.1 \mathrm{~mL}$ of $\mathrm{N}, \mathrm{N}$-dimethylformamide $(98 \% \mathrm{~min}$., Fluka) and $5.7 \mathrm{~mL}$ of absolute ethanol (puriss., Sigma-Aldrich). This was stirred overnight and electrospun on a rotating drum (Linari Biomedical, Pisa, Italy). The electrospinning was performed at $T=20{ }^{\circ} \mathrm{C}$ with an applied voltage of $15 \mathrm{kV}$ (high voltage power supply Spellmann CZE1000R), where the distance between needle and collector was fixed at $10 \mathrm{~cm}$ and the flow rate at $0.3 \mathrm{~mL} \mathrm{~h}^{-1}$ (syringe pump, KD Scientific, Holliston, MA, USA). To remove the carrier polymer and to allow the formation of inorganic fiber-in-tubes, the as-prepared fibers were submitted to calcination at $T=600^{\circ} \mathrm{C}$ for $4 \mathrm{~h}$ in air with a heating rate of $5{ }^{\circ} \mathrm{C} \mathrm{min}^{-1}$.

The doping level ( 5 at. $\% \mathrm{Nb}$ for NTO and 10 at.\% Sb for ATO) was chosen to reach the maximum electronic conductivity. The obtained supports were catalyzed with Pt NPs synthesized by a microwave-assisted polyol method [63]. In this method, a solution of $133 \mathrm{mg}$ of hexachloroplatinic acid $\left(\mathrm{H}_{2} \mathrm{PtCl}_{6} 6 \mathrm{H}_{2} \mathrm{O}, 99.9 \%\right.$ Alfa Aesar) in $95 \mathrm{~mL}$ of ethylene glycol (EG, $99.8 \%$, Sigma Aldrich) was prepared and its $\mathrm{pH}$ adjusted to 11.4 with a $1 \mathrm{M} \mathrm{NaOH}$ solution (98\%, Sigma Aldrich) in EG. This solution was heated to $T=120^{\circ} \mathrm{C}$ for $6 \mathrm{~min}$ in a microwave reactor (MiniFlow 200SS, Sairem, Lyon, France) operated at a power of $200 \mathrm{~W}$. The $\mathrm{pH}$ of the as-prepared Pt NP suspension was adjusted to 2 using $1 \mathrm{M}$ $\mathrm{H}_{2} \mathrm{SO}_{4}$ (95-98\%, Sigma Aldrich) in EG, then $60 \mathrm{mg}$ of the doped $\mathrm{SnO}_{2}$ fiber-in-tubes were added and the mixture left under stirring for $24 \mathrm{~h}$. The doped $\mathrm{SnO}_{2}$-supported $\mathrm{Pt}$ nanoparticles were recovered by filtration and washed with Milli-Q water and ethanol. They were first dried at $T=80^{\circ} \mathrm{C}$ for $24 \mathrm{~h}$, then heated at $T=160^{\circ} \mathrm{C}$ in air for $1 \mathrm{~h}$ to remove any traces of EG from the NP surface. 
The amount of Pt supported on the $\mathrm{SnO}_{2}$-based supports was assessed by X-ray fluorescence (XRF) with a PANalytical Axios Max spectrometer fitted with a Rh $(4 \mathrm{~kW})$ tube, equipped with a LiF200 crystal and Omnian software. Samples were prepared by grinding $50 \mathrm{mg}$ of each electrocatalyst with $25 \mathrm{mg}$ of cellulose. The resulting powder was then placed in the center of a cavity containing $\mathrm{H}_{3} \mathrm{BO}_{3}$ (the matrix) and subsequently pressed to obtain a $32 \mathrm{~mm}$-diameter pellet with scanned surface of ca. $1.1 \mathrm{~cm}^{2}$. The same protocol was used to prepare seven standards from 15 to $45 \mathrm{Pt}$ wt. $\%$. using Pt black (Alfa Aesar, Haverhill, MA, USA) and ATO or NTO to obtain calibration lines. The Pt loading evaluated by XRF was $33 \mathrm{wt} . \%$ on NTO and $37 \mathrm{wt} . \%$ on ATO.

\subsection{Accelerated Stress Test-EU Harmonised Test Protocols for PEMFC MEA Testing in Single Cell Configuration for Automotive Applications}

\subsubsection{Preparation of Membrane Electrode Assemblies (MEAs) with Pt/ATO and Pt/NTO}

A catalyst ink was prepared with $7.6 \mathrm{mg}$ of Pt/ATO ( $8.5 \mathrm{mg}$ of Pt/NTO), $36.4 \mu \mathrm{L}$ (or $41.2 \mu \mathrm{L}$ ) of a 5 wt.\% Nafion ${ }^{\circledR}$ EW1100 solution (Sigma-Aldrich), $1.5 \mathrm{~mL}$ (or $1.7 \mathrm{~mL}$ ) of water, and $4.5 \mathrm{~mL}$ (or $5.0 \mathrm{~mL}$ ) of ethanol. After $10 \mathrm{~min}$ ultrasonication, it was sprayed onto an $8 \mathrm{~cm}^{2}$ Teflon sheet placed over a heating pad at $T=80^{\circ} \mathrm{C}$. The prepared catalyst layer with a loading of $0.35 \mathrm{mg} \mathrm{Pt} \mathrm{cm}^{-2}$ was transferred onto the Nafion ${ }^{\circledR} 212$ membrane (Ion Power), previously treated in acid as detailed elsewhere [54] by hot-pressing at $T=140{ }^{\circ} \mathrm{C}$ for $90 \mathrm{~s}$ at $18.8 \mathrm{MPa}$ to produce a catalyst coated membrane. Finally, the anode (a gas diffusion electrode Baltic Fuel Cell, with platinum loading of $0.5 \mathrm{mg} \mathrm{cm}^{-2}$ ) and the gas diffusion layer (Sigracet $10 \mathrm{BC}$ ) were hot-pressed under the same conditions to obtain the MEA.

\subsubsection{Description of the Accelerated Stress Test}

The MEAs were mounted in single fuel cell hardware, and polarization curves were recorded in galvanostatic mode under $\mathrm{H}_{2} / \mathrm{O}_{2}$ (stoichiometry 1.5/2, 2 bar absolute pressure) after overnight conditioning at $j=0.4 \mathrm{~A} \mathrm{~cm}^{-2}$ at $100 \% \mathrm{RH}$ and $T=80{ }^{\circ} \mathrm{C}$. The MEAs were then cycled in on/off conditions: during the "on" phase, a load of $j=1.5 \mathrm{~A} \mathrm{~cm}^{-2}$ was applied to the cell, whereas during the "off" phase, the load was set to $j=0$, with the cell voltage $(U)$ being recorded during the "on" phase. The protocol was applied after measuring the beginning of test (BoT) stable average current density at $U=0.65 \mathrm{~V}$, considered as $100 \%$ current density of the on/off profile. The current density was then increased to $j=1.5 \mathrm{~A} \mathrm{~cm}^{-2}$. This value was maintained for $30 \mathrm{~min}$ and then decreased to the initial current density where the cell voltage was measured. Afterwards, the load was disconnected and the reactant supply at the cell inlet stopped without purging until the cell cooled down to room temperature. These conditions were held for $30 \mathrm{~min}$, after which the initial operating conditions were reset. The cycle was repeated until the cell voltage at the recorded current density had decreased by $10 \%$ of its initial value (in practice, the end of test, EoT, was reached after 35 cycles, which corresponds to $56 \mathrm{~h}$ ). Polarization curves were measured (and compared) at BoT and EoT.

To identify and quantify any element leaching from the supported catalyst, the cathode exhaust water was collected and analyzed (a total amount of $2 \mathrm{~L}$ of exhaust water was collected at EoT). Aliquots $(20 \mathrm{~mL})$ were withdrawn every $5 \mathrm{on} / \mathrm{off}$ cycles; any solid phase was dissolved by adding $1.0 \mathrm{~mL}$ of aqua regia, and the obtained solutions were analyzed by ICP-MS (Agilent 7900).

\subsection{Test in Planar Fuel Cell Configuration}

\subsubsection{Preparation of MEAs with Pt/ATO and Pt/NTO}

The Pt/ATO and Pt/NTO cathode catalyst inks were prepared by mixing the catalyst powders with a 20 wt.\%. Nafion ${ }^{\circledR}$ emulsion (DuPont de Nemours), water, and ethanol. The quantities of each ink constituent was calculated so that the resulting ink contained $1.5 \mathrm{wt} . \%$ of solid matter; the Nafion ${ }^{\circledR}$ content in the solid matter was $15 \mathrm{wt} . \%$ and the ratio of ethanol to water in the solvent was 60:40. The Pt/C (Tanaka TEC10E70TPM) anode catalyst ink was prepared by mixing the catalyst powder with 
a 20 wt.\%. Nafion ${ }^{\circledR}$ emulsion (DuPont de Nemours), water, and ethanol. The quantities of each ink constituent was calculated so that the resulting ink contained $7 \mathrm{wt}$.\% of solid matter, the Nafion content in the solid matter was $23 \mathrm{wt} \%$, and the ratio of ethanol to water in the solvent was 60:40. The ink homogenization process consisted of $1 \mathrm{~h}$ of ultrasonication followed by $15 \mathrm{~min}$ of stirring at $2000 \mathrm{rpm}$.

Coating of the Nafion ${ }^{\circledR}$ NR212 membrane (DuPont de Nemours) was carried out with a SonoTek ExactaCoat spraying system equipped with an Accumist nozzle and syringe pump. The membrane was held under vacuum at $T=80{ }^{\circ} \mathrm{C}$. The coating area was a series of eight cells of dimensions $6 \times 1.5 \mathrm{~cm}^{2}$ (distance between separate cells $0.20 \mathrm{~cm}$ ). The Pt loadings for the anode and cathode sides were programmed for 0.5 and $1.0 \mathrm{mg} \mathrm{cm}^{-2}$, respectively. Real Pt loadings were verified by mass measurements and were 0.80 and 0.95 for Pt/ATO and Pt/NTO cathodes, respectively.

Eight pairs of Freudenberg (IX92 CX316) gas diffusion layers (GDLs) were hot-pressed on the anode and cathode sides of the catalyst coated membranes at $T=140{ }^{\circ} \mathrm{C}$ and $60 \mathrm{~kg} \mathrm{~cm}^{-2}$ with a thermoplastic elastomer gasket material. The PACRETE assembly process for connecting the 8 individual cells in series is patented by PaxiTech and consists of connecting the anode of one pair of electrodes to the cathode of the adjacent pair of electrodes with a metal-coated nonwoven material supplied by Pragma Industries.

\subsubsection{Description of the Test}

The PaxiTech 8PE PACRETE fuel cell is an air-breathing system that operates at atmospheric pressure on the air side and in dead-end mode on the hydrogen side. It was supplied with hydrogen at $0 \% \mathrm{RH}$ and 1.5 bar. The water produced by the FC is eliminated as water vapor. Electrochemical tests were carried out in an environmental test chamber (Climats) at $25^{\circ} \mathrm{C}$ and $30 \% \mathrm{RH}$.

The specifications for the operation of an 8PE PACRETE fuel cell are $5 \mathrm{~W}$ peak power and $3 \mathrm{~W}$ nominal power and are operated at a "high" voltage, between $0.65<U<0.75 \mathrm{~V}$ per cell (i.e., $5.2<U<$ $6 \mathrm{~V}$ for 8 PE system).

The electrochemical tests were carried out using a BioLogic VS.P potentiostat coupled with a BioLogic VMP-3B5 multichannel potentiostat. The test profile consisted of measuring the open circuit voltage for a $5 \mathrm{~min}$ period, a chronoamperometry at $U=5.2 \mathrm{~V}\left(U=0.65 \mathrm{~V}\right.$ cell $\left.{ }^{-1}\right)$ for $30 \mathrm{~min}$, a polarization curve in galvanostatic mode and a chronoamperometry at $U=6 \mathrm{~V}\left(U=0.75 \mathrm{~V}\right.$ cell $\left.{ }^{-1}\right)$ for $30 \mathrm{~min}$. This test protocol was cycled for $850 \mathrm{~h}$. The hydrogen volume was purged once a day.

\subsubsection{Postmortem Characterization of MEA}

In order to shed light on possible heterogeneities of ageing within the thickness of the MEA, thin slices of MEA obtained by ultramicrotomy were further observed by transmission electron microscopy (TEM). Ultramicrotomed samples were prepared by embedding small pieces $\left(1 \mathrm{~cm}^{2}\right)$ of the fresh and aged MEA in Epoxy ${ }^{\circledR}$ resin. The slicing of the samples was carried out with an ultramicrotome (Leica ${ }^{\circledR}$ EM UC6) equipped with a (Diatome ${ }^{\circledR}$ ultra $35^{\circ}$ ) diamond knife, so that $70-90$ nm-thick slices were obtained. Each ultramicrotomed slice of fresh/aged MEAs was then immobilized on a TEM copper grid baring a Lacey carbon membrane (200 mesh, Lacey formvar/carbon, Ted Pella). The TEM observations were performed with a Jeol 2010 microscope operated at $200 \mathrm{kV}$; its point-to-point resolution was $0.19 \mathrm{~nm}$. Ten different zones were analyzed by energy dispersive X-ray spectroscopy $(\mathrm{X}$-EDS) to determine the average $\mathrm{M} /(\mathrm{M}+\mathrm{Sn})$ at.\% ratio, with $\mathrm{M}$ the doping element $(\mathrm{Sb}$ or $\mathrm{Nb})$.

\section{Results and Discussion}

\subsection{Accelerated Stress Test_- "EU Harmonised Test Protocols for PEMFC MEA Testing in Single Cell Configuration for Automotive Applications"}

Pt-catalyzed ATO and NTO loose tubes were submitted to the accelerated stress test (AST), implying on/off cycles and low potentials described in the "EU Harmonised Test Protocols for PEMFC MEA Testing in Single Cell Configuration for Automotive Applications" of the Fuel Cells and Hydrogen 
Joint Undertaking (FCHJU) [64]. This protocol, implemented specifically for Pt/C, aims at stressing the fuel cell core components by instantaneous and alternating phases of "on" and "off" loads leading to frequent changes in pressure and temperature. Moreover, due to the polarization at a rather high current density of $j=1.5 \mathrm{~A} \mathrm{~cm}^{-2}$, this test stresses the cathode to relatively low voltage regimes. The complete characterization of the Pt/ATO electrodes degradation upon this AST is reported elsewhere [59], while the present work focuses on the comparison of the differently doped supports ATO and NTO in a range of operating conditions.

The performance of the MEAs comprising a Pt/ATO and Pt/NTO cathode catalyst layers before and after completion of the accelerated stress test is depicted in Figure 1. The two I-V curves presented open circuit voltage of $U=0.97 \mathrm{~V}$ and were similar at very low current density, in agreement with the similar ORR activity observed ex situ [65]. At higher current density, the MEA comprising the Pt/NTO cathode showed high ohmic drop, which may be attributed to the lower electronic conductivity of the NTO support (the electronic conductivities of $\mathrm{Pt} / \mathrm{ATO}$ and $\mathrm{Pt} / \mathrm{NTO}$ were determined from resistance measurements at $T=20{ }^{\circ} \mathrm{C}$ and were 1.02 and $0.02 \mathrm{~S} \mathrm{~cm}^{-1}$ respectively) [54]. At $j=0.6 \mathrm{~A} \mathrm{~cm}^{-2}$, this assembly reached a power density of $P=0.37 \mathrm{~W} \mathrm{~cm}^{-2}$ (vs. $P=0.43 \mathrm{~W} \mathrm{~cm}^{-2}$ for the MEA comprising ATO), while the maximum of $P=0.6 \mathrm{~W} \mathrm{~cm}^{-2}$ was reached at $j=1.4 \mathrm{~A} \mathrm{~cm}^{-2}$ (vs. $P=0.82 \mathrm{~W} \mathrm{~cm}^{-2}$ at $j=1.8 \mathrm{~A} \mathrm{~cm}^{-2}$ for the MEA comprising ATO). The results for Pt/ATO-based MEAs are consistent with those obtained by Dou et al. [66], but in contrast with Kakinuma et al. [67], who reported lower performance compared to Pt/NTO-based MEAs. This outcome was ascribed to Pt poisoning by Sn dissolution/reprecipitation occurring for the $\mathrm{Sb}$-doped oxide at low potential: by operating at cell voltages higher than $U=0.4 \mathrm{~V}$, the performance was inversed and higher for Pt/ATO-based MEA as in the present work.

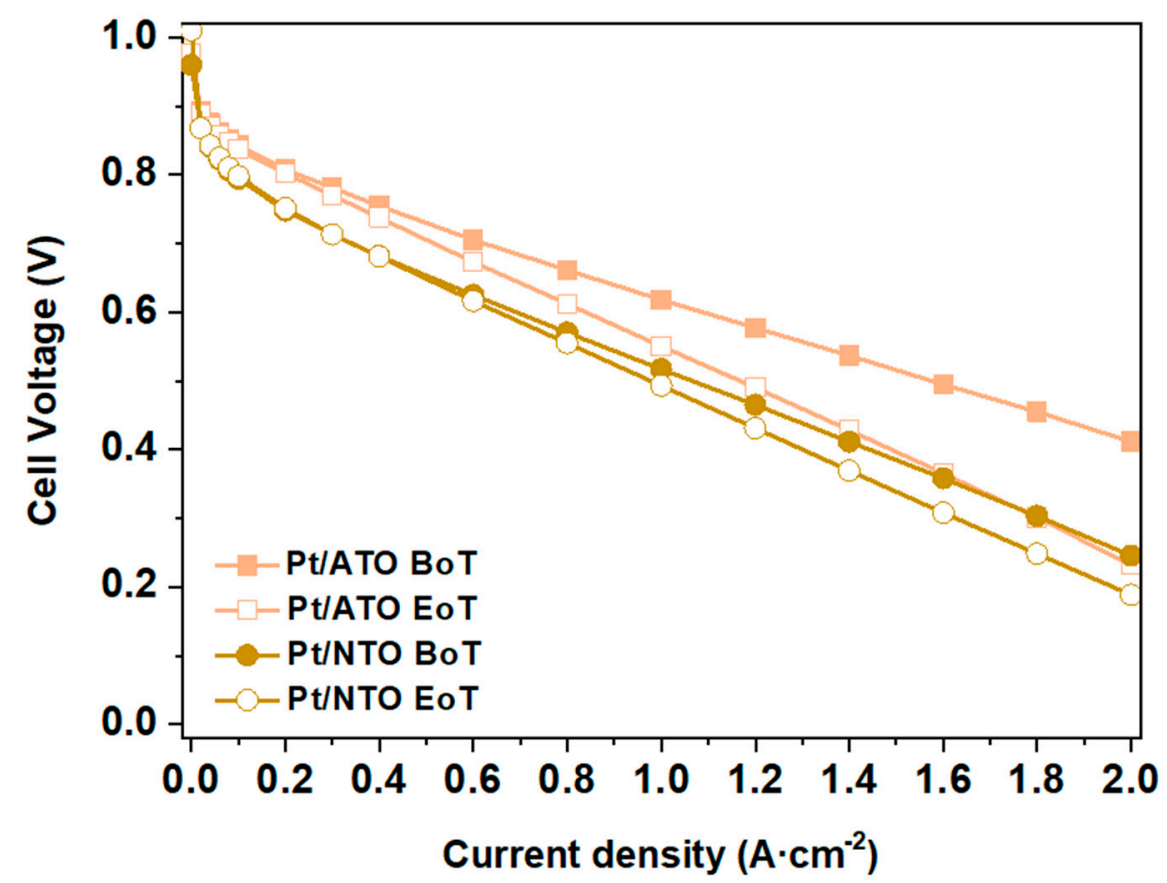

Figure 1. Polarization curves of membrane electrode assemblies including cathodes with Pt/ATO and $\mathrm{Pt} / \mathrm{NTO}\left(0.35 \mathrm{mg} \mathrm{Pt} \mathrm{cm}^{-2}\right.$ ) recorded under $\mathrm{H}_{2} / \mathrm{O}_{2}$ (stoichiometry 1.5/2.2 bar absolute pressure) at $\mathrm{T}=80{ }^{\circ} \mathrm{C}$ and $100 \%$ RH before (BoT) and after 35 AST cycles (EoT).

After the AST, the open circuit voltage (OCV) recorded for both MEAs was unchanged as well as the I-V curve at low current density, demonstrating insignificant degradation of the cathode electrocatalytic activity. However, for $j \geq 0.4 \mathrm{~A} \mathrm{~cm}^{-2}$, the performance of the Pt/NTO-based MEA slightly decreased, while that of the Pt/ATO-based MEA dramatically diminished, with a drop of $0.12 \mathrm{~V}$ at $j=1.5 \mathrm{~A} \mathrm{~cm}^{-2}$. This significant performance degradation for the assembly comprising ATO was 
already reported and explained with the instability of this support, which leaches its Sb dopant in low potential conditions [59].

To assess the possible leaching of the doping agent or of other components of the two cathodes, the systematic elemental analysis of the corresponding exhaust water was performed during the AST for 35 cycles: the elements composing the cathode materials $(\mathrm{Sn}, \mathrm{Nb}, \mathrm{Sb}, \mathrm{Pt})$ were analyzed by ICP-MS at every 5 cycles.

For the Pt/NTO cathode (Figure 2a), leaching of Sn and Pt occurred (at EoT 5.2 and $5.3 \mu \mathrm{g} \mathrm{L}^{-1}$, respectively), while no significant $\mathrm{Nb}$ was detected $\left(0.4 \mu \mathrm{g} \mathrm{L} \mathrm{L}^{-1}\right)$. In the case of the Pt/ATO cathode (Figure 2b), significantly lower amounts of Sn and Pt were detected (at EoT 0 and $0.8 \mu \mathrm{g} \mathrm{L}^{-1}$, respectively) but, as already mentioned, a high concentration of $\mathrm{Sb}\left(7.1 \mu \mathrm{g} \mathrm{L}^{-1}\right)$ was found in the exhaust water.
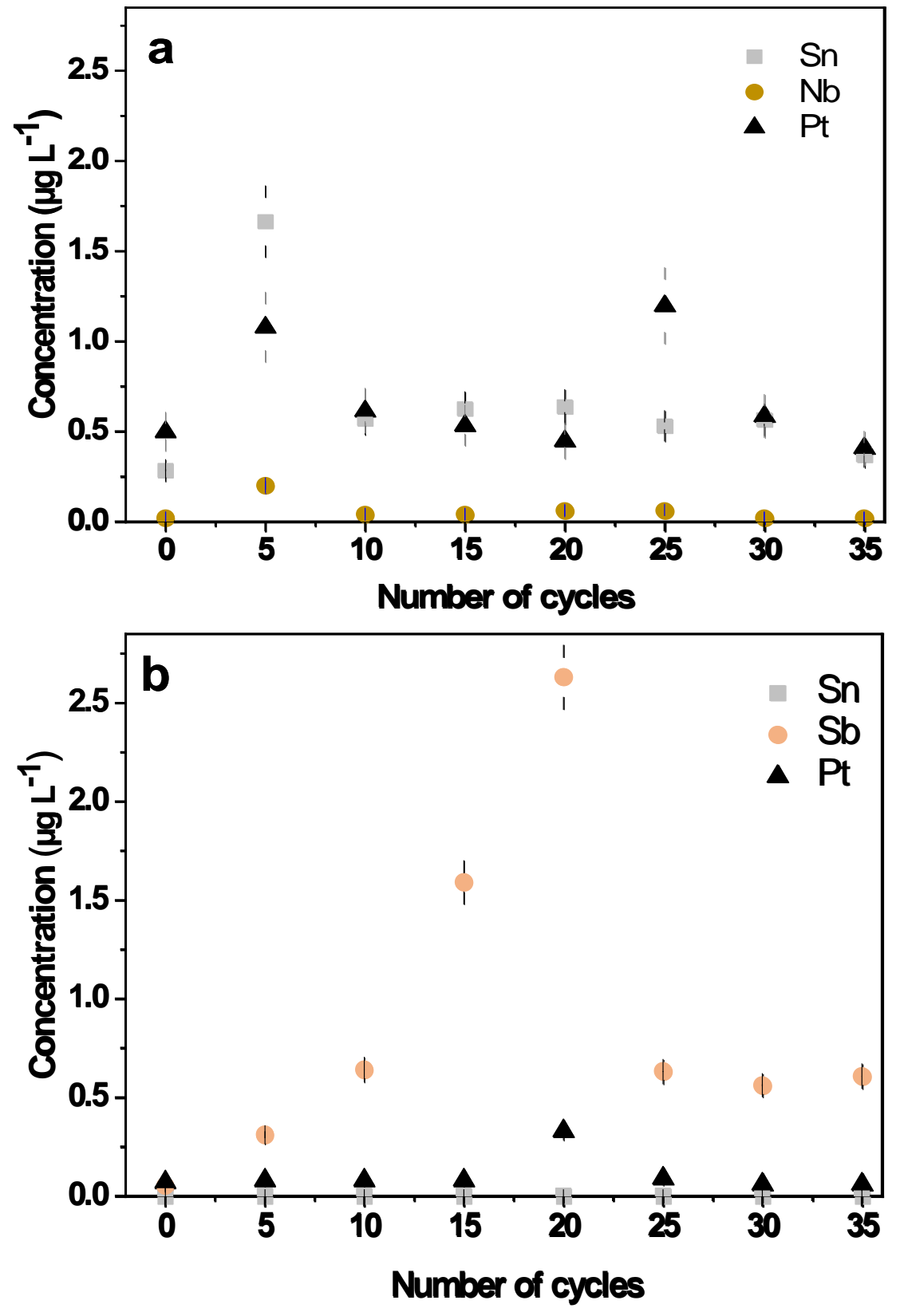

Figure 2. ICP-MS analysis of the selected elements $(\mathrm{Sn}, \mathrm{Nb}, \mathrm{Sb}, \mathrm{Pt})$ detected in the water recovered at the cathode side during start/stop cycling AST for Pt/NTO (a) and Pt/ATO-based MEAs (b). 
The preferential leaching of $\mathrm{Sb}$ vs. $\mathrm{Nb}$ can be explained by thermodynamic calculations, that show that in the AST conditions ( $\mathrm{pH} 0$ and potential around $0.4 \mathrm{~V}$ vs. RHE), niobium is present in its stable form $\left(\mathrm{Nb}_{2} \mathrm{O}_{5}\right)$, while antimony can be present as soluble species $\left(\mathrm{Sb}_{2} \mathrm{O}_{3}, \mathrm{Sb}_{2} \mathrm{O}_{5}\right.$, and $\left.\mathrm{SbO}^{+}\right)$[68].

\subsection{Test in Planar Fuel Cell Configuration}

Figure 3 shows the power at $U=0.65 \mathrm{~V} \mathrm{cell}^{-1}$ as a function of time for the Pt/ATO and Pt/NTO cathodes operated in the PEMFC air-breathing system. The activation time for the Pt/ATO fuel cell system was very long, which is normal for this type of air-breathing system operating at room temperature and pressure. Activation was non-existent for the Pt/NTO system. The performances were very low, and neither fuel cell system attained the nominal power of $P=3 \mathrm{~W}$. The aim of these tests was to check the feasibility and durability of the cathode catalyst materials Pt/ATO and Pt/NTO. Better performances would probably have been observed if, prior to these tests, optimization studies of both the ink compositions and the catalyst coating parameters had been carried out, which has not been feasible for the amount of catalyst synthesized for these tests.

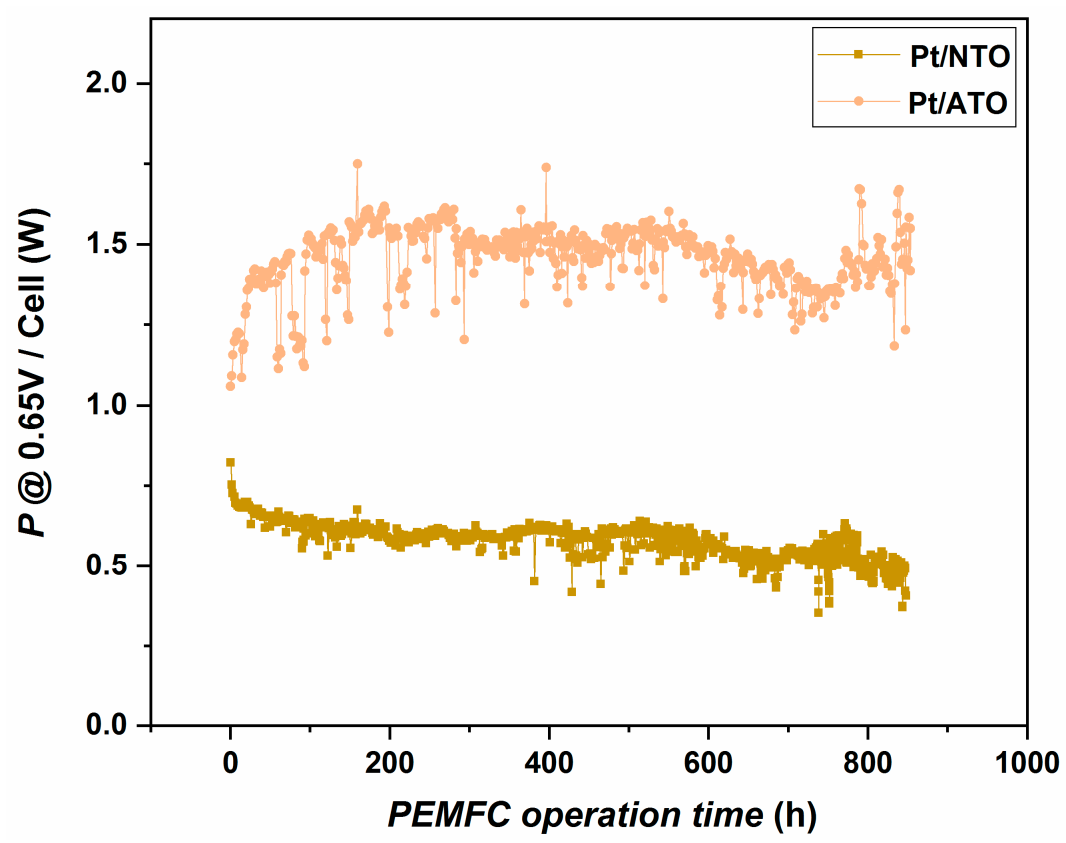

Figure 3. Chronoamperometry at $U=0.65 \mathrm{~V}$ for a PEMFC air-breathing system with Pt/ATO and $\mathrm{Pt} / \mathrm{NTO}$ cathode catalysts.

A decrease in the PEMFC performances is reported with time but at a degradation rate that was acceptable for these systems. Both Pt/ATO and Pt/NTO- based systems continued to operate at the end of the test after $850 \mathrm{~h}$ of continuous operation. Although the performances reached were lower-than-expected with these catalysts, they nevertheless demonstrate that $\mathrm{MO}_{\mathrm{x}}$ support can be employed with (some) success in real self-breathing PEFMC devices, even though a wealth of optimization would be desired to reach state-of-the-art performances (and obtaining these was beyond reach in this study). More than optimizing MEAs, we evaluated the catalysts post-tests.

Figure 4 displays representative TEM images obtained from ultramicrotomed thin slices of pristine and aged MEA. Observations have been made at both the PEM/cathode and cathode/GDL interfaces. The pristine MEAs are morphologically homogeneous; the Pt NPs synthesized by the polyol method are relatively well-dispersed on the ATO and NTO loose-tube supports. After ageing, it appears that the catalyst has significantly changed, particularly at the PEM/cathode interface. At this interface and whatever the nature of the dopant element, the loose-tube morphology of the oxide support is (at least partially) lost. Furthermore, classical Pt degradation mechanisms take place in this region. 
A pronounced aggregation of Pt NPs and a growth in size are noteworthy. These results can be explained by considering that a high $\mathrm{H}_{2}$ concentration (coming from the anode side) is present at the $\mathrm{PEM} /$ cathode interface, which consequently increases the probability for $\mathrm{Pt}^{\mathrm{z}}$ ions produced by Ostwald ripening to be reduced, thereby favoring the NP growth and aggregation via particle necking. These results are in agreement with previous ones obtained for $\mathrm{Pt}$ and $\mathrm{Pt}-\mathrm{Co}$ supported on carbon [69-73]. By contrast, the cathode/GDL interface appears to be unaffected and resembles pristine materials, probably because $\mathrm{Pt}^{\mathrm{z}+}$ ionic species produced close to the GDL (if any) are more prone to be washed by the water formed in the catalytic layer and to leave the cell. It is also important to have in mind that the local current density in the cathodic region located close to the GDL is smaller with respect to that located near the PEM, because of the longer ion path in the former region. Therefore, it is not surprising to note that the regions close to the GDL are more preserved than the ones neighboring the PEM.

Pristine MEA
Aged MEA
Interface PEM/Cathode

Aged MEA
Interface Cathode/GDL

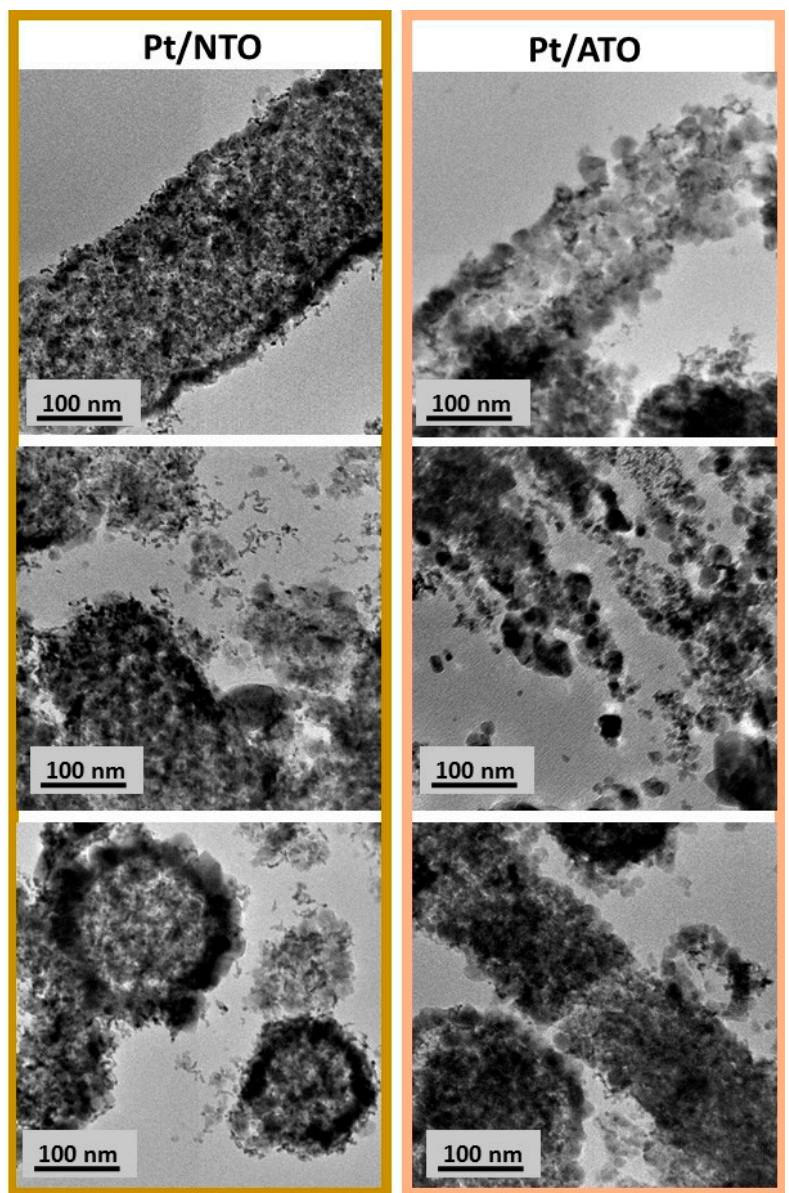

Figure 4. Representative TEM characterization of ultramicrotomed pristine/aged MEA to unravel morphological heterogeneities of ageing within the Pt/ATO and Pt/NTO cathode thickness.

To go further, X-EDS analyses were performed to monitor the extent of dissolution of the doping element $(\mathrm{Sb}$ or $\mathrm{Nb}$ ). Figure 5 displays the [dopant/(dopant $+\mathrm{Sn})]$ at.\%. ratio of the fresh and aged $\mathrm{Pt} / \mathrm{NTO}$ and $\mathrm{Pt} / \mathrm{ATO}$ cathode catalysts. Interestingly, the value of doping level initially targeted to maximize the electronic conductivity ( 5 at.\%. Nb for NTO and 10 at. $\%$. Sb for ATO) is very close to the one measured on the pristine electrocatalysts, showing that X-EDS analysis on MEAs is sufficiently reliable for such measurements. After $850 \mathrm{~h}$ of operation in PEMFC air-breathing system, the behaviors of NTO and ATO supports are different. In terms of dopant dissolution, NTO support appears to be more stable, since no change in the doping atomic content is reported for both PEM/cathode and cathode/GDL interfaces. For the ATO support, it has to be noted that $\mathrm{Sb}$ dissolution is more pronounced at the 
PEM/cathode interface following the morphological degradation on the Pt/ATO catalyst described previously. Despite the strongly different operating conditions, these results are in agreement with the ICP-MS measurements made after the AST presented in the first part on this study, showing very minor dissolution of $\mathrm{Nb}$ compared to $\mathrm{Sb}$. Here again, thermodynamic considerations on the stability of $\mathrm{Nb}$ oxide vs. Sb soluble oxide in the $\mathrm{pH}$ and potential conditions allow to rationalize this trend. At this stage, bridging post mortem analyses and performance losses are obvious, since the better stability of the $\mathrm{Nb}$ doping element translates into better performance stability. Summing up, the initially poor performance of $\mathrm{Pt} / \mathrm{NTO}$ support (with respect to $\mathrm{Pt} / \mathrm{ATO}$ ) is due to the lack of electronic conductivity (1.02 vs. $0.02 \mathrm{~S} \mathrm{~cm}^{-1}$ for Pt/ATO and Pt/NTO, respectively) but Pt/NTO appears to be more durable in operation, in agreement with the very stable doping level of this support.

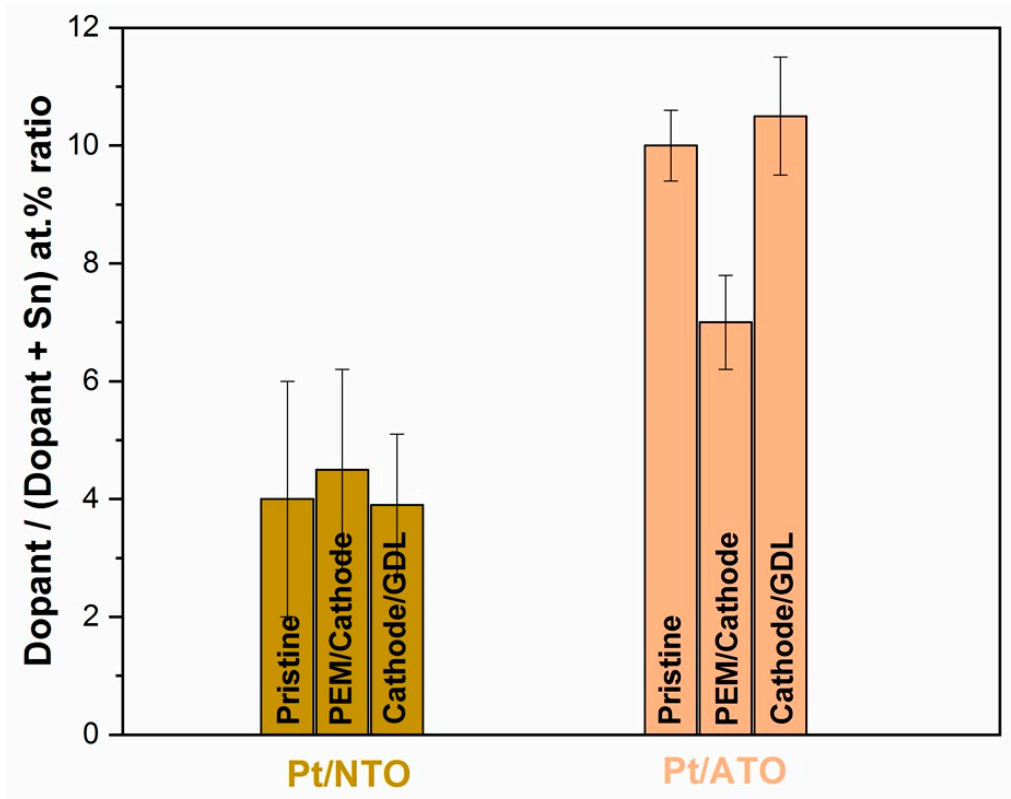

Figure 5. X-EDS analysis carried out on fresh and aged ultramicrotomed pristine/aged MEA to quantify heterogeneities of dopant content at the PEM/cathode and cathode/GDL interfaces.

\section{Conclusions}

The present study explores the effect of the nature of the doping element (niobium and antimony tin oxide, NTO and ATO respectively) on the PEMFC activity and stability. Two different protocols for ageing have been applied to Pt/NTO and Pt/ATO catalyst based on Pt NPs synthesized by the polyol method and deposited on doped tin oxide loose-tubes morphology. The first one is an accelerated stress test derived from the "EU Harmonised Test Protocols for PEMFC MEA Testing in Single Cell Configuration for Automotive Applications", and the second one is a specific real PEMFC test in planar air-breathing system which has lasted $850 \mathrm{~h}$. Even if the operating conditions of both tests are fully different, the conclusions regarding the performances and durability of the catalyst materials are close. Notably, this study highlights the greater performances of Pt/ATO cathodes compared to $\mathrm{Pt} / \mathrm{NTO}$ ones due to a lower electronic conductivity of the NTO support. In terms of stability and following thermodynamically considerations, antimony is more prone to dissolution than niobium in the harsh environment of a PEMFC cathode, as has been demonstrated by ICP-MS carried out in the exhaust water after operation and by X-EDS measurements on ultramicrotomed MEA.

Author Contributions: Conceptualization, S.C., A.M. and L.D.; methodology, S.C., A.M. and L.D.; validation, S.C., A.M. and L.D.; formal analysis, S.C., A.M. and L.D.; investigation, I.J.-M.; resources, X.X.; data curation, I.J.-M.; writing - original draft preparation, L.D., F.M., M.C., S.C., A.M. and R.M.; project administration, S.C., R.M. and F.M.; funding acquisition, S.C., R.M. and F.M. All authors have read and agreed to the published version of the manuscript. 
Funding: This research was funded by French National Research Agency through the SURICAT project (grant number ANR-12-PRGE-007), the European Union's Seventh Framework Program for the Fuel Cells and Hydrogen Joint Technology Initiative under grant agreement No. 325239 (FCH-JU project Nano-CAT) and the European Research Council under the European Union's Seventh Framework Programme (FP/2007-2013) / ERC Grant Agreement n. 306682. SC thanks the French IUF for its support.

Acknowledgments: The authors thank Christine Lancelon Pin (CERMAV—CNRS) for assistance in ultramicrotomy.

Conflicts of Interest: The authors declare no conflict of interest. The funders had no role in the design of the study; in the collection, analyses, or interpretation of data; in the writing of the manuscript, or in the decision to publish the results.

\section{References}

1. Guilminot, E.; Corcella, A.; Charlot, F.; Maillard, F.; Chatenet, M. Detection of $\mathrm{Pt}^{\mathrm{Z}+}$ ions and Pt nanoparticles inside the membrane of a used PEM fuel cell. J. Electrochem. Soc. 2007, 154, B96-B105. [CrossRef]

2. Dubau, L.; Castanheira, L.; Berthomé, G.; Maillard, F. An identical-location transmission electron microscopy study on the degradation of $\mathrm{Pt} / \mathrm{C}$ nanoparticles under oxidizing, reducing and neutral atmosphere. Electrochim. Acta 2013, 110, 273-281. [CrossRef]

3. Nikkuni, F.R.; Vion-Dury, B.; Dubau, L.; Maillard, F.; Ticianelli, E.A.; Chatenet, M. The role of water in the degradation of $\mathrm{Pt}_{3} \mathrm{Co} / \mathrm{C}$ nanoparticles: An identical location transmission electron microscopy study in polymer electrolyte environment. Appl. Catal. B 2014, 156-157, 301-306. [CrossRef]

4. Dubau, L.; Maillard, F.; Chatenet, M.; André, J.; Rossinot, E. Nanoscale compositional changes and modification of the surface reactivity of $\mathrm{Pt}_{3} \mathrm{Co} / \mathrm{C}$ nanoparticles during proton-exchange membrane fuel cell operation. Electrochim. Acta 2010, 56, 776-783. [CrossRef]

5. Dubau, L.; Maillard, F.; Chatenet, M.; Guétaz, L.; André, J.; Rossinot, E. Durability of $\mathrm{Pt}_{3} \mathrm{CoC}$ cathodes in a 16 Cell PEMFC stack: Macro/microstructural changes and degradation mechanisms. J. Electrochem. Soc. 2010, 157, B1887-B1895. [CrossRef]

6. Dubau, L.; Durst, J.; Maillard, F.; Chatenet, M.; Guétaz, L.; André, J.; Rossinot, E. Further insights into the durability of $\mathrm{Pt}_{3} \mathrm{Co} / \mathrm{C}$ electrocatalysts: Formation of $\mathrm{Pt}$ "hollow" nanoparticles induced by the Kirkendall effect. Electrochim. Acta 2011, 56, 10658-10667. [CrossRef]

7. Dubau, L.; Lopez-Haro, M.; Castanheira, L.; Durst, J.; Chatenet, M.; Bayle-Guillemaud, P.; Guétaz, L.; Caqué, N.; Rossinot, E.; Maillard, F. Probing the structure, the composition and the ORR activity of $\mathrm{Pt}_{3} \mathrm{Co} / \mathrm{C}$ nanocrystallites during a $3422 \mathrm{~h}$ PEMFC ageing test. Appl. Catal. B 2013, 142-143, 801-808. [CrossRef]

8. Iojoiu, C.; Guilminot, E.; Maillard, F.; Chatenet, M.; Sanchez, J.Y.; Claude, E.; Rossinot, E. Membrane and active layer degradation following PEMFC steady-state operation. J. Electrochem. Soc. 2007, 154, B1115-B1120. [CrossRef]

9. Roen, L.M.; Paik, C.H.; Jarvi, T.D. Electrocatalytic corrosion of carbon support in PEMFC cathodes. Electrochem. Solid State Lett. 2004, 7, A19-A22. [CrossRef]

10. Stevens, D.A.; Hicks, M.T.; Haugen, G.M.; Dahn, J.R. Ex situ and in situ stability studies of PEMFC catalysts. J. Electrochem. Soc. 2005, 152, A2309-A2315. [CrossRef]

11. Linse, N.; Gubler, L.; Scherer, G.G.; Wokaun, A. The effect of platinum on carbon corrosion behavior in polymer electrolyte fuel cells. Electrochim. Acta 2011, 56, 7541-7549. [CrossRef]

12. Artyushkova, K.; Pylypenko, S.; Dowlapalli, M.; Atanassov, P. Structure-to-property relationships in fuel cell catalyst supports: Correlation of surface chemistry and morphology with oxidation resistance of carbon blacks. J. Power Sources 2012, 214, 303-313. [CrossRef]

13. Durst, J.; Lamibrac, A.; Charlot, F.; Dillet, J.; Castanheira, L.F.; Maranzana, G.; Dubau, L.; Maillard, F.; Chatenet, M.; Lottin, O. Degradation heterogeneities induced by repetitive start/stop events in proton exchange membrane fuel cell: Inlet vs. outlet and channel vs. land. Appl. Catal. B 2013, 138-139, 416-426. [CrossRef]

14. Zhao, Z.; Castanheira, L.; Dubau, L.; Berthomé, G.; Crisci, A.; Maillard, F. Carbon corrosion and platinum nanoparticles ripening under open circuit potential conditions. J. Power Sources 2013, 230, 236-243. [CrossRef]

15. Castanheira, L.; Dubau, L.; Mermoux, M.; Berthomé, G.; Caqué, N.; Rossinot, E.; Chatenet, M.; Maillard, F. Carbon corrosion in proton-exchange membrane fuel cells: From model experiments to real-life operation in membrane electrode assemblies. ACS Catal. 2014, 4, 2258-2267. [CrossRef] 
16. Dubau, L.; Castanheira, L.; Chatenet, M.; Maillard, F.; Dillet, J.; Maranzana, G.; Abbou, S.; Lottin, O.; De Moor, G.; El Kaddouri, A.; et al. Carbon corrosion induced by membrane failure: The weak link of PEMFC long-term performance. Int. J. Hydrogen Energy 2014, 39, 21902-21914. [CrossRef]

17. Castanheira, L.; Silva, W.O.; Lima, F.H.B.; Crisci, A.; Dubau, L.; Maillard, F. Carbon corrosion in proton-exchange membrane fuel cells: Effect of the carbon structure, the degradation protocol, and the gas atmosphere. ACS Catal. 2015, 5, 2184-2194. [CrossRef]

18. Appleby, A.J. Corrosion in low and high temperature fuel cells-An overview. Corrosion 1987, 43, $398-408$. [CrossRef]

19. Maass, S.; Finsterwalder, F.; Frank, G.; Hartmann, R.; Merten, C. Carbon support oxidation in PEM fuel cell cathodes. J. Power Sources 2008, 176, 444-451. [CrossRef]

20. Binder, H.; Kohling, A.; Richter, K.; Sandstede, G. Über die anodische oxydation von aktivkohlen in wässrigen elektrolyten. Electrochim. Acta 1964, 9, 255-274. [CrossRef]

21. McBreen, J.; Olender, H.; Srinivasan, S.; Kordesch, K.V. Carbon supports for phosphoric acid fuel cell electrocatalysts: Alternative materials and methods of evaluation. J. Appl. Electrochem. 1981, 11, 787-796. [CrossRef]

22. Antonucci, P.L.; Romeo, F.; Minutoli, O.; Alderucci, E.; Giordano, N. Electrochemical corrosion behavior of carbon black in phosphoric acid. Carbon 1988, 26, 197-203. [CrossRef]

23. Gallagher, K.G.; Fuller, T.F. Kinetic model of the electrochemical oxidation of graphitic carbon in acidic environments. Phys. Chem. Chem. Phys. 2009, 11, 11557-11567. [CrossRef]

24. Maillard, F.; Bonnefont, A.; Micoud, F. An EC-FTIR study on the catalytic role of Pt in carbon corrosion. Electrochem. Comun. 2011, 13, 1109-1111. [CrossRef]

25. Shukla, A.K.; Hamnett, A.; Roy, A.; Barman, S.R.; Sarma, D.D.; Alderucci, V.; Pino, L.; Giordano, N. An X-ray photoelectron spectroscopic study on platinised carbons with varying functional-group characteristics. J. Electroanal. Chem. 1993, 352, 337-343. [CrossRef]

26. Shukla, A.K.; Ravikumar, M.K.; Roy, A.; Barman, S.R.; Sarma, D.D.; Arico, A.S.; Antonucci, V.; Pino, L.; Giordano, N. Electrooxidation of methanol in sulfuric-acid electrolyte on platinized-carbon electrodes with several functional-group characteristics. J. Electrochem. Soc. 1994, 141, 1517-1522. [CrossRef]

27. Antonucci, P.L.; Alderucci, V.; Giordano, N.; Cocke, D.L.; Kim, H. On the role of surface functional-groups in Pt carbon interaction. J. Appl. Electrochem. 1994, 24, 58-65. [CrossRef]

28. Alderucci, V.; Pino, L.; Antonucci, P.L.; Roh, W.; Cho, J.; Kim, H.; Cocke, D.L.; Antonucci, V. XPS study of surface oxidation of carbon-supported Pt catalysts. Mater. Chem. Phys. 1995, 41, 9-14. [CrossRef]

29. Coloma, F.; Sepulveda-Escribano, A.; Fierro, J.L.G.; Rodriguez-Reinoso, F. Crotonaldehyde hydrogenation over bimetallic $\mathrm{Pt}-\mathrm{Sn}$ catalysts supported on pregraphitized carbon black. Effect of the preparation method. Appl. Catal. A 1996, 148, 63-80. [CrossRef]

30. Lim, K.H.; Lee, W.H.; Jeong, Y.; Kim, H. Analysis of carbon corrosion in anode under fuel starvation using on-line mass spectrometry in polymer electrolyte membrane fuel cells. J. Electrochem. Soc. 2017, 164, F1580-F1586. [CrossRef]

31. Mittermeier, T.; Weiß, A.; Hasché, F.; Hübner, G.; Gasteiger, H.A. PEM fuel cell start-up/shut-down losses vs temperature for non-graphitized and graphitized cathode carbon supports. J. Electrochem. Soc. 2017, 164, F127-F137. [CrossRef]

32. Kangasniemi, K.H.; Condit, D.A.; Jarvi, T.D. Characterization of Vulcan electrochemically oxidized under simulated PEM fuel cell conditions. J. Electrochem. Soc. 2004, 151, E125-E132. [CrossRef]

33. Zhao, Z.; Dubau, L.; Maillard, F. Evidences of the migration of Pt crystallites on high surface area carbon supports in the presence of reducing molecules. J. Power Sources 2012, 217, 449-458. [CrossRef]

34. Willsau, J.; Heitbaum, J. The influence of Pt-activation on the corrosion of carbon in gas diffusion electrodes-A DEMS study. J. Electroanal. Chem. Interfacial Electrochem. 1984, 161, 93-101. [CrossRef]

35. Lafforgue, C.; Maillard, F.; Martin, V.; Dubau, L.; Chatenet, M. Degradation of carbon-supported platinum-group-metal electrocatalysts in alkaline media studied by in situ Fourier transform infrared spectroscopy and identical-location transmission electron microscopy. ACS Catal. 2019, 9, 5613-5622. [CrossRef]

36. Lamibrac, A.; Maranzana, G.; Dillet, J.; Lottin, O.; Didierjean, S.; Durst, J.; Dubau, L.; Maillard, F.; Chatenet, M. Local degradations resulting from repeated start-ups and shutdowns in proton exchange membrane fuel cell (PEMFC). Energy Procedia 2012, 29, 318-324. [CrossRef] 
37. Dillet, J.; Spernjak, D.; Lamibrac, A.; Maranzana, G.; Mukundan, R.; Fairweather, J.; Didierjean, S.; Borup, R.L.; Lottin, O. Impact of flow rates and electrode specifications on degradations during repeated startups and shutdowns in polymer-electrolyte membrane fuel cells. J. Power Sources 2014, 250, 68-79. [CrossRef]

38. Sasaki, K.; Takasaki, F.; Noda, Z.; Hayashi, S.; Shiratori, Y.; Ito, K. Alternative electrocatalyst support materials for polymer electrolyte fuel cells. ECS Trans. 2010, 33, 473-482.

39. Hartmann, W. Elektrische Untersuchungen an oxydischen Halbleitern. Z. Phys. 1936, 102, 709-733. [CrossRef]

40. Schäfer, H.; Bergner, D.; Gruehn, R. Beiträge zur Chemie der Elemente Niob und Tantal. LXXI. Die thermodynamische Stabilität der sieben zwischen 2,00 und 2,50 O/Nb existierenden Phasen. Z. Anorg. Allg. Chem. 1969, 365, 31-50. [CrossRef]

41. Shannon, R.D. Revised effective ionic radii and systematic studies of interatomic distances in halides and chalcogenides. Acta Crystallogr. Sect. A 1976, 32, 751-767. [CrossRef]

42. Takasaki, F.; Matsuie, S.; Takabatake, Y.; Noda, Z.; Hayashi, A.; Shiratori, Y.; Ito, K.; Sasaki, K. Carbon-free Pt electrocatalysts supported on $\mathrm{SnO}_{2}$ for polymer electrolyte fuel cells: Electrocatalytic activity and durability. J. Electrochem. Soc. 2011, 158, B1270-B1275. [CrossRef]

43. Takabatake, Y.; Noda, Z.; Lyth, S.M.; Hayashi, A.; Sasaki, K. Cycle durability of metal oxide supports for PEFC electrocatalysts. Int. J. Hydrogen Energy 2014, 39, 5074-5082. [CrossRef]

44. Masao, A.; Noda, S.; Takasaki, F.; Ito, K.; Sasaki, K. Carbon-free Pt electrocatalysts supported on $\mathrm{SnO}_{2}$ for polymer electrolyte fuel cells. Electrochem. Solid State Lett. 2009, 12, B119-B122. [CrossRef]

45. Huang, S.-Y.; Ganesan, P.; Park, S.; Popov, B.N. Development of a titanium dioxide-supported platinum catalyst with ultrahigh stability for polymer electrolyte membrane fuel cell applications. J. Am. Chem. Soc. 2009, 131, 13898-13899. [CrossRef]

46. Lee, K.S.; Park, I.S.; Cho, Y.H.; Jung, D.S.; Jung, N.; Park, H.Y.; Sung, Y.E. Electrocatalytic activity and stability of Pt supported on Sb-doped $\mathrm{SnO}_{2}$ nanoparticles for direct alcohol fuel cells. J. Catal. 2008, 258, 143-152. [CrossRef]

47. Bauer, A.; Chevallier, L.; Hui, R.; Cavaliere, S.; Zhang, J.; Jones, D.; Rozière, J. Synthesis and characterization of $\mathrm{Nb}-\mathrm{TiO}_{2}$ mesoporous microsphere and nanofiber supported Pt catalysts for high temperature PEM fuel cells. Electrochim. Acta 2012, 77, 1-7. [CrossRef]

48. Chevallier, L.; Bauer, A.; Cavaliere, S.; Hui, R.; Rozière, J.; Jones, D.J. Mesoporous nanostructured Nb-doped titanium dioxide microsphere catalyst supports for PEM fuel cell electrodes. ACS Appl. Mater. Interfaces 2012, 4, 1752-1759. [CrossRef]

49. Kakinuma, K.; Chino, Y.; Senoo, Y.; Uchida, M.; Kamino, T.; Uchida, H.; Deki, S.; Watanabe, M. Characterization of Pt catalysts on $\mathrm{Nb}$-doped and $\mathrm{Sb}$-doped $\mathrm{SnO}_{2-\delta}$ support materials with aggregated structure by rotating disk electrode and fuel cell measurements. Electrochim. Acta 2013, 110, 316-324. [CrossRef]

50. Liu, Y.; Mustain, W.E. High stability, high activity Pt/ITO oxygen reduction electrocatalysts. J. Am. Chem. Soc. 2013, 135, 530-533. [CrossRef]

51. Fabbri, E.; Rabis, A.; Kötz, R.; Schmidt, T.J. Pt nanoparticles supported on Sb-doped $\mathrm{SnO}_{2}$ porous structures: Developments and issues. Phys. Chem. Chem. Phys. 2014, 16, 13672-13681. [CrossRef] [PubMed]

52. Senoo, Y.; Taniguchi, K.; Kakinuma, K.; Uchida, M.; Uchida, H.; Deki, S.; Watanabe, M. Cathodic performance and high potential durability of $\mathrm{Ta}-\mathrm{SnO}_{2-\delta}$-supported Pt catalysts for PEFC cathodes. Electrochem. Commun. 2015, 51, 37-40. [CrossRef]

53. Cavaliere, S.; Jiménez-Morales, I.; Ercolano, G.; Savych, I.; Jones, D.; Rozière, J. Highly Stable PEMFC electrodes based on electrospun antimony-doped $\mathrm{SnO}_{2}$. ChemElectroChem 2015, 2, 1966-1973. [CrossRef]

54. Savych, I.; Subianto, S.; Nabil, Y.; Cavaliere, S.; Jones, D.; Rozière, J. Negligible degradation upon in situ voltage cycling of a PEMFC using an electrospun niobium-doped tin oxide supported Pt cathode. Phys. Chem. Chem. Phys. 2015, 17, 16970-16976. [CrossRef]

55. Cognard, G.; Ozouf, G.; Beauger, C.; Jiménez-Morales, I.; Cavaliere, S.; Jones, D.; Rozière, J.; Chatenet, M.; Maillard, F. Pt nanoparticles supported on niobium-doped tin dioxide: Impact of the support morphology on Pt utilization and electrocatalytic activity. Electrocatalysis 2017, 8, 51-58. [CrossRef]

56. Cognard, G.; Ozouf, G.; Beauger, C.; Berthomé, G.; Riassetto, D.; Dubau, L.; Chattot, R.; Chatenet, M.; Maillard, F. Benefits and limitations of $\mathrm{Pt}$ nanoparticles supported on highly porous antimony-doped tin dioxide aerogel as alternative cathode material for proton-exchange membrane fuel cells. Appl. Catal. B 2017, 201, 381-390. [CrossRef] 
57. Cognard, G.; Ozouf, G.; Beauger, C.; Dubau, L.; López-Haro, M.; Chatenet, M.; Maillard, F. Insights into the stability of Pt nanoparticles supported on antimony-doped tin oxide in different potential ranges. Electrochim. Acta 2017, 245, 993-1004. [CrossRef]

58. Ozouf, G.; Cognard, G.; Maillard, F.; Guétaz, L.; Chatenet, M.; Heitzmann, M.; Jacques, P.A.; Beauger, C. $\mathrm{Sb}$-doped $\mathrm{SnO}_{2}$ aerogels based catalysts for proton exchange membrane fuel cells: Pt deposition routes, electrocatalytic activity and durability. J. Electrochem. Soc. 2018, 165, F3036-F3044. [CrossRef]

59. Jimenez-Morales, I.; Cavaliere, S.; Dupont, M.; Jones, D.J.; Rozière, J. On the stability of antimony doped tin oxide supports in proton exchange membrane fuel cell and water electrolysers. Sustain. Energy Fuels 2019, 3, 1526-1535. [CrossRef]

60. Geiger, S.; Kasian, O.; Mingers, A.M.; Mayrhofer, K.J.J.; Cherevko, S. Stability limits of tin-based electrocatalyst supports. Sci. Rep. UK 2017, 7, 4595. [CrossRef]

61. Kakinuma, K.; Kim, I.-T.; Senoo, Y.; Yano, H.; Watanabe, M.; Uchida, M. Electrochemical oxidation of hydrolyzed poly oxymethylene-dimethyl ether by PtRu catalysts on $\mathrm{Nb}$-doped $\mathrm{SnO}_{2-\delta}$ supports for direct oxidation fuel cells. ACS Appl. Mater. Interfaces 2014, 6, 22138-22145. [CrossRef] [PubMed]

62. Cavaliere, S.; Subianto, S.; Savych, I.; Tillard, M.; Jones, D.J.; Rozière, J. Dopant-driven nanostructured loose-tube $\mathrm{SnO}_{2}$ architectures: Alternative electrocatalyst supports for proton exchange membrane fuel cells. J. Phys. Chem. C 2013, 117, 18298-18307. [CrossRef]

63. Larsen, M.J.; Jiménez Morales, I.; Cavaliere, S.; Zajac, J.; Jones, D.J.; Rozière, J.; Kaluža, L.; Gulková, D.; Odgaard, M. Development of tailored high-performance and durable electrocatalysts for advanced PEM fuel cells. Int. J. Hydrogen Energy 2017, 42, 7166-7176. [CrossRef]

64. Tsotridis, G.; Pilenga, A.; De Marco, G.; Malkow, T. EU Harmonised Test Protocols for PEMFC MEA Testing in Single Cell Configuration for Automotive Applications; Publications Office of the European Union: Luxembourg, 2015.

65. Jiménez-Morales, I.; Cavaliere, S.; Jones, D.; Rozière, J. Strong metal-support interaction improves activity and stability of Pt electrocatalysts on doped metal oxides. Phys. Chem. Chem. Phys. 2018, 20, 8765-8772. [CrossRef] [PubMed]

66. Dou, M.; Hou, M.; Liang, D.; Lu, W.; Shao, Z.; Yi, B. $\mathrm{SnO}_{2}$ nanocluster supported Pt catalyst with high stability for proton exchange membrane fuel cells. Electrochim. Acta 2013, 92, 468-473. [CrossRef]

67. Kakinuma, K.; Uchida, M.; Kamino, T.; Uchida, H.; Watanabe, M. Synthesis and electrochemical characterization of $\mathrm{Pt}$ catalyst supported on $\mathrm{Sn}_{0.96} \mathrm{Sb}_{0.04} \mathrm{O}_{2-\delta}$ with a network structure. Electrochim. Acta 2011, 56, 2881-2887. [CrossRef]

68. Pourbaix, M. Atlas of Electrochemical Equilibria in Aqueous Solutions; National Association of Corrosion Engineers: Houston, TX, USA, 1974.

69. Ferreira, P.J.; la O', G.J.; Shao-Horn, Y.; Morgan, D.; Makharia, R.; Kocha, S.; Gasteiger, H.A. Instability of $\mathrm{Pt} / \mathrm{C}$ electrocatalysts in proton exchange membrane fuel cells. J. Electrochem. Soc. 2005, 152, A2256-A2271. [CrossRef]

70. Chen, S.; Gasteiger, H.A.; Hayakawa, K.; Tada, T.; Shao-Horn, Y. Platinum-alloy cathode catalyst degradation in proton exchange membrane fuel cells: Nanometer-scale compositional and morphological changes. J. Electrochem. Soc. 2010, 157, A82-A97. [CrossRef]

71. Dubau, L.; Castanheira, L.; Maillard, F.; Chatenet, M.; Lottin, O.; Maranzana, G.; Dillet, J.; Lamibrac, A.; Perrin, J.-C.; Moukheiber, E.; et al. A review of PEM fuel cell durability: Materials degradation, local heterogeneities of aging and possible mitigation strategies. Wiley Interdiscip. Rev. Energy Environ. 2014, 3, 540-560. [CrossRef]

72. Dubau, L.; Durst, J.; Guétaz, L.; Maillard, F.; Chatenet, M.; André, J.; Rossinot, E. Evidences of through-plane heterogeneities of ageing in a proton-exchange membrane fuel cell. ECS Electrochem. Lett. 2012, 1, F13-F15. [CrossRef]

73. Dubau, L.; Durst, J.; Maillard, F.; Chatenet, M.; André, J.; Rossinot, E. Heterogeneities of aging within a PEMFC MEA. Fuel Cells 2012, 12, 188-198. [CrossRef]

(C) 2020 by the authors. Licensee MDPI, Basel, Switzerland. This article is an open access article distributed under the terms and conditions of the Creative Commons Attribution (CC BY) license (http://creativecommons.org/licenses/by/4.0/). 